Canadian Journal of Family and Youth, 13(2), 2021, pp. 205-209

ISSN 1718-9748@ University of Alberta

http://ejournals, library,ualberta.ca/index/php/cjfy

\title{
Eckler, Rebecca. (2019). Blissfully Blended Bullshit: The Uncomfortable Truth of Blending Families. Toronto: Dundurn Press.
}

\section{Reviewed by: Angelina Lee, MacEwan University}

In "Blissfully Blended Bullshit," Rebecca Eckler explores the harsh, uncomfortable reality of what really happens behind the closed doors of blended families. Beyond what picture-perfect social media posts portray and what "so-called experts" acknowledge, blending households comes with tremendous changes and commitments that people in traditional families would not imagine. With her effective storytelling skills infused with humour, she successfully demonstrates how blending affects everyone through the various examples and experiences of her friends and herself. This book highlights the unexpected problems that arise with blending and unblending families, which the author calls "bullshit" throughout the story.

The first "bullshit" she mentions is the blending partner's former relationship. "The truest thing about blended families is that saying, 'You're marrying the ex,"' Eckler's friend says (p. 38). When the new partner has children with their former spouse, the marriage comes with complicated child custody schedules and hence the uncomfortable necessity to build a trusting relationship with the ex. She explains that living with and becoming a parent of someone else's child can be very challenging when the child's blood mother is not supportive. One example Eckler provides is her daughter Rowan's overnight summer camp, which she wanted her two stepchildren to join so badly at the early days of blending that she was even willing to chip in for the cost. Bonus children, the kids who come with blending, often face 
difficulties adjusting to their new lives after blending: having two mothers, two homes, and a stepsibling, Rowan, in the author's case. This camp bonding never happens because the children's biological mother disagrees for financial reasons. The author feels her husband's ex deliberately denied and ruined the three children's best opportunity to connect and bond with one another forever. Having the entire family life tied to another person, who can dictate the bonus children's upbringing, is one of the "bullshits" that comes along with blending (p. 152).

Eckler adds that everyone in a blended family constantly fights one another for love and attention not to feel left out, creating jealousy and ridiculous fights and slights. Her bonus children fear their father is paying more attention to his new spouse over themselves, Rowan worries her mother is giving more love to bonus children, and the author feels her husband is unfair because his phone screensaver shows "a family picture" that does not include her daughter and herself. The feeling of being neglected or left out is a much bigger issue in a blended household than in a typical, traditional family. The "Hi/Bye Fight," which she calls the debate over who says hi or bye first when the bonus children enter or exit the front door, is one of the first issues that arise from this particular feeling in Eckler's family. From this point, every little thing starts to bother the author: picture frames in each family member's rooms that never feature all the family members, her husband's grocery shopping that seems biased in favour of his blood children, and his amazing cooking skills that only show when his kids are eating. This constant fight to be someone's priority and not to feel left out is the central "bullshit" that stresses everyone in the family, even her husband's dog that does not like Baby Holt, the youngest child who gets everyone's attention.

The following question highlights the book's most significant theme: "Is blood really 
thicker than water"? (p. 67) Eckler faces this unpleasant subject when her husband's mother accidentally says, "it's not the same when they're not your own" (p. 63). It profoundly hurts and offends her that one of the family members outwardly admitted that love is unequal in a blended family. Through many fights and arguments with her husband during the marriage over circumstances that depict the unequal love, she realizes the uncomfortable truth that she herself puts Rowan first before everyone else. She cannot help that she values the precious bond she has built with her daughter since her last divorce more than anything else, and her husband cannot hide his Dad Guilt toward his children that arise from the busy custody schedule. This understanding does not mean a complete acceptance of the unfairness. It still stings when everything your partner does seems to favour only his blood children, and the treatment your precious child receives does not show the same effort.

Eckler comments that love is about respect, and respect always has to be earned in a blended family, especially when it comes to bonus children (p. 71). This requires her, as a stepmom, to be extra attentive and cautious, even if that means attempting to be the bigger person in a situation like the $\mathrm{Hi} /$ Bye Fight. It sometimes means not expecting any appreciation cards or gifts on Mother's Day or a birthday despite how hurtful and disappointing it is because you are not their biological mother. It could also mean you cannot attend certain family events because you are unwelcome. As an example, Eckler illustrates her emotional breakdown on the day she helped one of her husband's daughters shop for a prom dress. She explains the devastating moment of realization that her opinions and help did not matter to the daughter as long as her biological mother had a say over text messages (p. 145). Also, Eckler cannot go to her prom later because the husband's ex will be there, and the daughter would be uncomfortable 
to have both mothers attend. Feeling unappreciated, hypersensitive, and discarded, she states that she is exhausted from trying to please everyone to make her family all blissfully blended (p. 157).

Throughout the book, Eckler demonstrates her detest and skepticism toward "so-called experts" on the Internet who give advice and guidance on functioning a blended family. She resents not only the fact that they never talk about the daily "bullshit" issues that she desperately needs help with but also that she did not follow their well-known advice of planning and discussing everything before blending. She wonders if her everyday arguments over the bills and financial matters with her husband were preventable if they had talked about finances and property ownerships before their quick marriage, blinded by love. Becoming a hider is another common characteristic of blenders Eckler points out that experts fail to acknowledge (p. 141). After years of trying to make the blending work, people become a hider to avoid fights or loneliness. While she tells her friend about hiding in the bedroom, she explains, "blending is harder than I ever could have imagined, as is dealing with the feelings that boil over when it seems like everyone has taken over the entire house and I am like a stranger or a guest in my own house....Many times, I feel like the people in my family just don't care about me at all" (p. 142). This isolation illustrates her breaking point, which will eventually lead to her divorce and unblending.

Eckler concludes by introducing the issues pertaining to the second divorce and unblending. According to her reading, sixty-six percent of blended families separate, and there is a seventy-five percent chance that the next partner she finds after divorcing will have children. People do not like to be portrayed as serial divorcees, so they try to fix the problems and make 
the family work; however, the weekly couple's therapy is expensive, people do not improve overnight, and thus daily arguments repeat. "No, we can't and won't ever make blended splendid again. The lid is off. Shit is flying everywhere" (p. 195). This specific quote when she decides to divorce her husband visually illustrates the cover image of the book: a working kitchen blender without its lid, splashing fruit parts and liquid all over the place. Eckler argues that the harsh reality of unblending is that you divorce not only your partner but also part of your family, the children you gained when blending. And the children also lose their stepsiblings, who have been together for years.

Replete with illustrative narration and humorous expressions, "Blissfully Blended Bullshit" accomplishes Eckler's intended goal. The book offers authentic evidence of how blending affects everyone in the family. I found it a little bit repeating when she talks about how marrying someone with a kid is also marrying their ex and their family, and when she complains about how her ex-husband did not like Rowan's "one last good night" visit in her room (p. 165). She also does not provide references for the statistics above and when she states, "some experts say it can take up to five years for everyone to be comfortable in a blended family" (p. 60). I believe the data would be more reliable if she cited the exact sources.

Nevertheless, her book was amusing to read and brought numerous emotions out of me. I learned complex, varying perspectives of a single mother, a child of divorced parents, and members of a blended family. Thus, I believe sociologists who study diverse family forms and their impacts on women's mental health and children will find this book helpful. I would also recommend it to anyone interested in learning what blending households truly means. 